\title{
EFEK QUALITY OF WORK LIFE TERHADAP KINERJA KARYAWAN DENGAN LAMA KERJA SEBAGAI VARIABEL MODERATING (STUDI PADA PT. PLN (PERSERO) UIP3B SUMATERA UPT MEDAN)
}

\author{
Vira Sherina ${ }^{1}$, Tapi Rondang Ni Bulan², Winda Ardiani ${ }^{3 *}$ \\ 1,2,3 Universitas Harapan Medan, Jalan Imam Bonjol No. 35 Medan \\ *Penulis Korespondensi; Email: tapinibulan@gmail.com ${ }^{1}$, virasherina8@gmail.com², windaardiani.chan@gmail.com³
}

\begin{abstract}
Abstrak
Penelitian ini bertujuan untuk mengetahui pengaruh Quality of Work Life terhadap Kinerja Karyawan dengan Lama Kerja sebagai variabel moderating pada perusahaan PT. PLN (Persero) UIP3B Sumatera UPT Medan. Metode analisis pada penelitian ini adalah uji analisis regresi moderasi untuk mengetahui apakah variabel moderating akan memperkuat atau memperlemah hubungan antara variabel independen dan variabel dependen yang diteliti. Seluruh populasi yang menjadi sampel, yaitu 130 orang pegawai pada perusahaan PT. PLN (Persero) UIP3B Sumatera UPT Medan. Hasil penelitian ini menyatakan Quality of Work Life memiliki pengaruh yang positif dan signifikan terhadap Kinerja Karyawan, sehingga dapat disimpulkan bahwa Lama Kerja merupakan variabel moderating yang memperkuat terhadap hubungan antara Quality of Work Life dengan Kinerja Karyawan.
\end{abstract}

Kata Kunci: Kualitas kehidupan kerja, kinerja karyawan, lama kerja.

\begin{abstract}
This study aimed to determine the effect of the Quality of Work Life on Employee Performance with Length of Work as a Moderating variable at PT. PLN (Persero) UIP3B Sumatera UPT Medan. The method of analysis in this study was the moderation regression analysis test to determine whether the moderating variable will strengthen or weaken the relationship between the independent variable and the dependent variable studied and to justify how significant the influence of the independent and dependent variables was either directly or indirectly through the moderating variable. In this study the entire population sampled, namely 130 employees at the company PT. PLN (Persero) UIP3B Sumatera UPT Medan. The results of this study indicated that the Quality of Work Life had a significant effect on employee performance and length of work as a moderating variable had a positive effect on the relationship between the Quality of Work Life and employee performance.
\end{abstract}

Keywords: Quality of work life, employee performance, length of work.

\section{Pendahuluan}

Sumber daya manusia merupakan bagian yang cukup penting dalam pencapaian tujuan, visi dan misi organisasi yang telah ditetapkan, maka perusahaan bertanggungjawab untuk memelihara kualitas kehidupan kerja dan membina tenaga kerja agar bersedia memberikan kontribusinya secara optimal untuk mencapai tujuan perusahaan (Pruijt, 2003). Pendapat lain menurut Cascio (2006) Kualitas kehidupan kerja mencakup aktivitasaktivitas yang ada di dalam perusahaan, yang diarahkan untuk meningkatkan suatu kondisi kehidupan kerja yang dapat membangkitkan semangat kerja dalam melaksanakan tugas untuk mencapai sasaran perusahaan.

Penelitian ini dilaksanakan di PT. PLN (Persero) UIP3BS UPT Medan yang merupakan salah satu perusahaan milik negara (BUMN) yang bergerak di bidang kelistrikan negara dan menjadi Induk Pusat dan Penyaluran Pengatur Beban di 22 Gardu Induk serta berfokus pada Pelayanan dan Pengaliran Listrik di Sumatera Bagian Utara. Peraturan Pemerintah No. 18 tahun 1972 mempertegas kedudukan PLN sebagai Perusahaan Umum Listrik Negara dengan hak, wewenang, dan tanggung jawab membangkitkan, menyalurkan dan mendistribusikan tenaga Listrik ke seluruh wilayah Negara Republik Indonesia.

Selain itu, karena tingginya jumlah pelanggan PLN dan tuntutan masyarakat agar mendapatkan pelayanan listrik yang memadai tanpa adanya gangguan dan pemadaman listrik, maka kualitas kehidupan kerja (Quality of 
Work Life) sangat diperlukan, karena karyawan PT. PLN (Persero) UIP3BS UPT Medan dituntut harus memberikan kontribusinya secara optimal untuk mencapai tujuan perusahaan serta bertanggung jawab dapat melayani masyarakat yang menjadi konsumen listrik.

Semakin tingginya tuntutan masyarakat akan listrik yang memadai maka dapat memengaruhi kinerja karyawan. Kurangnya kinerja atau semangat kerja karyawan biasanya apabila perusahaan tidak berusaha memelihara kualitas kehidupan kerja (Quality of Work Life) yang baik. Keberhasilan organisasi dalam meningkatkan kinerjanya sangat bergantung pada kualitas sumber daya manusia yang bersangkutan dalam bekerja selama berada pada organisasi tersebut. Banyaknya peranan dan tuntutan yang dirasakan oleh individu dapat diartikan semakin bertambah pula tugas dan kewajiban yang harus dijalani. Adanya perintah, tugas, atau kewajiban berbeda secara bersamaan yang diterima individu yang akan mengakibatkan terabaikannya hal-hal tersebut. Penerapan teori kualitas kehidupan kerja (Quality of Work Life) tidak dibatasi pada perubahan konteks suatu pekerjaan tapi juga termasuk memanusiakan lingkungan kerja untuk memperbaiki martabat dan harga diri pekerja.

Kemampuan karyawan tercermin dari kinerjanya. Kinerja pada umumnya diartikan sebagai hasil kerja secara kualitas dan kuantitas yang dicapai oleh seorang pegawai dalam melaksanakan tugasnya sesuai dengan tanggung jawab yang diberikan kepadanya (Mangkunegara, 2009). Keberhasilan organisasi dalam meningkatkan kinerjanya sangat bergantung pada kualitas sumber daya manusia yang bersangkutan dalam bekerja selama berada pada organisasi tersebut. Kinerja merupakan landasan bagi pencapaian tujuan suatu organisasi. Namun pencapaian tujuan itu tidak sesederhana yang dipikirkan oleh pihak manajemen. Terdapat kendala-kendala utama yang timbul terutama dapat berasal dari para karyawan sebagai anggota organisasi, seperti menurunnya semangat kerja ditandai dengan kurangnya kontribusi karyawan dalam organisasi.

Keterkaitan antara kinerja dan lama kerja disebabkan oleh semakin lama seseorang bekerja di suatu pekerjaan maka keterampilan dan kemampuan karyawan tersebut dalam melakukan pekerjaan semakin meningkat. Karyawan dengan masa kerja yang lama harus diperhatikan kualitas kehidupan kerjanya oleh perusahaan agar semangat kerja dan kinerja karyawan tidak menurun. Rasa kejenuhan yang muncul dari begitu lama karyawan bekerja akan dapat memengaruhi kondisi psikologi karyawan.

Menurut Aprilyanti (2017) masa kerja adalah tingkat penguasaan seseorang dalam pelaksanaan aspekaspek teknik peralatan dan teknik pekerjaan, sedangkan untuk lama kerja adalah semakin lama seseorang bekerja di suatu pekerjaan maka keterampilan dan kemampuan karyawan tersebut dalam melakukan pekerjaan semakin meningkat. Menurut Kamus Besar Bahasa Indonesia, Lama kerja adalah lama waktu untuk melakukan suatu kegiatan atau lama waktu seseorang sudah bekerja. Waktu kerja bagi seseorang menentukan kesehatan yang bersangkutan, efisiensi, efektivitas dan produktivitas kerjanya. Semakin lama masa kerja seorang tenaga kerja seharusnya keterampilan dan kemampuan melakukan pekerjaan semakin meningkat.

Pengalaman seseorang melaksanakan pekerjaan secara terus menerus mampu meningkatkan kedewasaan teknisnya. Hal tersebut akan berpengaruh terhadap kinerja karyawan. Karyawan yang sudah lama bekerja biasanya lebih tenang dalam menghadapi masalah pekerjaan, serta mudah memahami cara kerja organisasi, dan penyesuaian atau kerjasama antar karyawan dapat mudah terjalin. Karyawan dengan masa kerja yang lama harus diperhatikan kualitas kehidupan kerjanya oleh perusahaan agar semangat kerja dan kinerja karyawan tidak menurun. Rasa kejenuhan yang muncul dari begitu lama karyawan bekerja akan dapat memengaruhi kondisi psikologi karyawan.

Peneliti mengungkapkan beberapa alasan mengapa masalah kualitas kehidupan kerja (Quality of Work Life) di PT. PLN (Persero) UIP3BS UPT Medan perlu diangkat ke permukaan ini antara lain, yaitu: 1) Masalah kualitas kehidupan kerja (Quality of Work Life) secara non-fisik yaitu hubungan manusia yang kurang terjalin dengan baik antara sebagian karyawan, sedangkan secara fisik yaitu ruangan di beberapa bagian bidang kerja yang kurang nyaman dan tidak cukup luas sehingga menyebabkan rasa jenuh bagi karyawan berada di dalamnya, namun hal tersebut belum pernah diangkat ataupun diteliti dalam organisasi, padahal posisinya sangat penting kaitannya dengan kinerja dan produktivitas para pegawainya, 2) dengan terwujudnya kualitas kehidupan kerja yang baik, maka diharapkan dapat mendukung kinerja pegawai menjadi lebih baik dan optimal, 3) pemahaman akan kualitas kehidupan kerja yang disertai dengan pemahaman terhadap cara-cara untuk memperbaiki kualitas kerja adalah penting sekali demi kelangsungan organisasi tersebut. Selain itu peningkatan kualitas kehidupan kerja yang ditetapkan oleh perusahaan sangat menguntungkan bagi karyawan, perusahaan dan konsumen. Bagi karyawan, kualitas kehidupan kerja dapat memuaskan kebutuhan pribadi karyawan. Bagi perusahaan ataupun organisasi dapat mengurangi tingkat absensi dan perputaran tenaga kerja, serta peningkatan produktivitas bagi konsumen. 
Berdasarkan fenomena di atas peneliti tertarik untuk mengambil topik yang berhubungan dengan kualitas kehidupan kerja (Quality of Work Life) terhadap tinggi atau rendahnya kinerja karyawan sebagai landasan bagi pencapaian tujuan suatu organisasi. karena diasumsikan terdapat pengaruh antara kualitas kehidupan kerja (Quality of Work Life) terhadap kinerja karyawan, baik pengaruh secara parsial maupun pengaruh secara simultan.

\section{Kajian Teoritis dan Hipotesis \\ Quality of Work Life}

Menurut Ivancevich (2007) kualitas kehidupan kerja merupakan cara pandang manajemen tentang manusia, pekerja dan organisasi. Quality of Work Life dimaksudkan dalam meningkatkan harga diri karyawan, memperkenalkan perubahan dalam budaya organisasi serta memperbaiki keadaan fisik dan emosional para karyawan. Dengan adanya peningkatan perubahan dan perbaikan tersebut, karyawan akan memiliki kesempatan untuk tumbuh dan berkembang. Beberapa faktor yang memengaruhi kualitas kehidupan kerja adalah sebagai berikut (Hanefah et al. yang di kutip Hadi, 2008):

1. Restrukturisasi kerja, diukur dengan pengaturan jadwal kerja, kesempatan menerapkan keterampilan, kesempatan meningkatkan keterampilan, ketersediaan SOP (Standard Operating Procedure)/peraturan, dan kesempatan unjuk kemampuan.

2. Partisipasi Kerja, dengan melihat kemampuan meningkatkan komunikasi internal dan kelompok, kemampuan meningkatkan koordinasi, kemampuan meningkatkan kapabilitas, dan kemampuan melibatkan diri dalam proses pembuatan berbagai keputusan organisasional secara proporsional.

3. Sistem Imbalan, diukur dengan melihat kebutuhan hidup, jaminan kelangsungan bekerja/penghasilan, kesesuaian imbalan dengan tugas dan tanggung jawab, kesesuaian gaji dengan kebutuhan pekerja dan peranan pekerjaan/penghasilan yang diperoleh bagi ekonomi keluarga pekerja.

4. Lingkungan Kerja, diukur dengan melihat kondisi keamanan lingkungan kerja, jaminan kebersihan dan kesehatan lingkungan kerja, kondisi umum kenyamanan di lingkungan kerja, jaminan keselamatan kerja, serta dukungan kondisi lingkungan terhadap keberhasilan kerja.

Indikator-indikator Quality of Work Life menurut Walton (1974) dalam Zin (2004), sebagai berikut:

1. Pertumbuhan dan pengembangan, yaitu terdapatnya kemungkinan untuk mengembangkan kemampuan dan tersedianya kesempatan untuk menggunakan ketrampilan atau pengetahuan yang dimiliki karyawan.

2. Partisipasi, yaitu adanya kesempatan untuk berpartisipasi atau terlibat dalam pengambilan keputusan yang memengaruhi langsung maupun tidak langsung terhadap pekerjaan.

3. Sistem imbalan yang inovatif, yaitu bahwa imbalan yang diberikan kepada karyawan memungkinkan mereka untuk memuaskan berbagai kebutuhannya sesuai dengan standar hidup karyawan yang bersangkutan dan sesuai dengan standar pengupahan dan penggajian yang berlaku di pasaran kerja.

4. Lingkungan kerja, yaitu tersedianya lingkungan kerja yang kondusif, termasuk di dalamnya penetapan jam kerja, peraturan yang berlaku kepemimpinan serta lingkungan fisik.

\section{Lama Kerja}

Menurut Aprilyanti (2017) masa kerja adalah tingkat penguasaan seseorang dalam pelaksanaan aspekaspek teknik peralatan dan teknik pekerjaan, sedangkan untuk lama kerja adalah semakin lama seseorang bekerja di suatu pekerjaan maka keterampilan dan kemampuan karyawan tersebut dalam melakukan pekerjaan semakin meningkat.

Indikator-indikator Lama Kerja menurut Handoko (2007), sebagai berikut:

1. Tingkat kepuasan kerja

2. Stres lingkungan kerja

3. Pengembangan karir

4. Kompensasi hasil kerja

\section{Kinerja Karyawan}

Menurut Mangkunegara (2009) kinerja adalah kerja secara kualitas dan kuantitas yang dicapai oleh seorang pegawai dalam melaksanakan tugasnya sesuai dengan tanggung jawab yang diberikan kepadanya. Kinerja dapat diketahui dan diukur jika individu atau sekelompok karyawan telah mempunyai kriteria atau standar 
keberhasilan tolak ukur yang ditetapkan oleh organisasi (Moeheriono, 2009). Indikator-indikator Kinerja Karyawan menurut Robbins (2006), sebagai berikut:

1. Kualitas. Kualitas kerja diukur dari persepsi karyawa terhadap kualitas pekerjaan yang dihasilkan serta kesempurnaan tugas terhadap keterampilan dan kemampuan karyawan.

2. Kuantitas merupakan jumlah yang dihasilkan dinyatakan dalam istilah seperti jumlah unit, jumlah siklus aktivitas yang diselesaikan.

3. Ketepatan Waktu merupakan tingkat aktivitas diselesaikan awal waktu yang dinyatakan, dilihat dari sudut koordinasi dengan hasil output serta memaksimalkan waktu yang tersedia untuk aktivitas lain.

4. Efektivitas merupakan tingkat penggunaan sumber daya organisasi (tenaga, uang, teknologi, bahan baku) dimaksimalkan dengan maksud menaikkan hasil dari setiap unit dalam penggunaan sumber daya.

5. Kemandirian merupakan tingkat seseorang karyawan yang nantinya akan dapat menjalankan tugas kerjanya.

6. Komitmen kerja merupakan suatu tingkat yang mana karyawan mempunyai komitme kerja dengan instansi dan tanggung jawab karyawan terhadap kantor.

\section{Pengaruh Quality of Work Life Terhadap Kinerja Karyawan}

Menurut Setiyadi, Wartini, dan Wijayanto (2016), Quality of Work Life berpengaruh positif terhadap kinerja karyawan. Apabila implikasi Quality of Work Life karyawan lebih ditingkatkan, maka kinerja karyawan akan meningkat pula, begitu juga sebaliknya apabila implikasi Quality of Work Life karyawan rendah maka kinerja karyawan akan menurun.

$H_{1:}$ Quality of Work Life berpengaruh positif dan signifikan terhadap Kinerja Karyawan.

\section{Hubungan Moderasi}

Menurut Rahmadani (2017), lama bekerja berhasil memoderasi antara kepuasan kerja dengan kinerja. Kepuasan kerja merupakan salah satu yang berkenaan dengan Quality of Work Life, maka karyawan yang mempunyai masa kerja yang lama merasa puas dalam bekerja, begitu pula sebaliknya, karyawan yang masih baru akan menyesuaikan diri dengan lingkungan kerja sehingga kepuasan karyawan terhadap pekerjaan belum tinggi, dan kinerja yang dihasilkan belum sesuai dengan yang diharapkan oleh perusahaan.

$H_{2:}$ Lama kerja memoderasi pengaruh Quality of Work Life terhadap Kinerja Karyawan.

\section{Kerangka Konseptual Penelitian}

Berdasarkan latar belakang, tinjauan teoritis dan penelitian terdahulu sebagaimana yang telah diuraikan, maka peneliti membuat kerangka konseptual seperti dalam Gambar 1, yaitu:

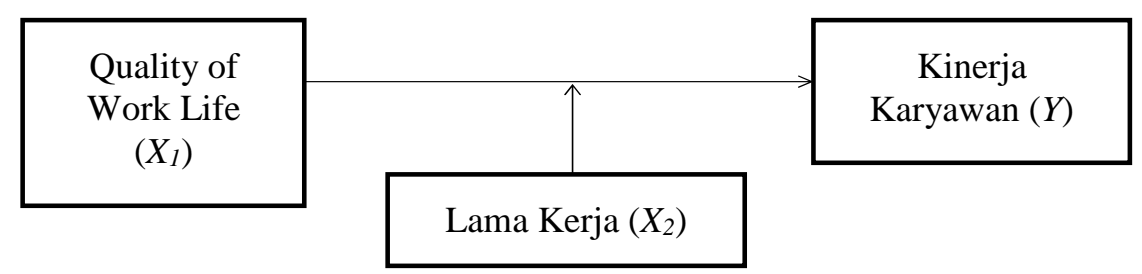

Gambar 1. Kerangka konseptual pengaruh quality of work life terhadap kinerja karyawan dan lama kerja sebagai pemoderasi

\section{Metode Penelitian}

Metode penelitian pada dasarnya adalah suatu cara ilmiah agar bisa mendapatkan data dengan tujuan dan kegunaan tertentu. Pada penelitian kali ini penulis menggunakan penelitian asosiatif. Menurut Sugiyono (2016), penelitian asosiatif yaitu penelitian yang dipakai untuk mengetahui pengaruh atau hubungan antar dua variabel ataupun lebih. Dalam penentuan sampel, penulis menggunakan metode untuk menghitung jumlah sampel yaitu menggunakan rumus Slovin dengan taraf signifikansi 5\%.

Sumber data yang digunakan pada penelitian ini adalah data primer, yaitu data yang diperoleh peneliti langsung dari objek yang diteliti. Data primer pada penelitian ini dengan cara memberikan kuesioner pada responden sebagai objek penelitian dengan menggunakan skala likert. Teknik pengumpulan data yang penulis gunakan didalam penelitian kali ini adalah survei dengan menggunakan kuesioner. 


\section{Analisis Data dan Pembahasan \\ Uji Validitas}

Uji validitas dilakukan untuk mengukur sah ataupun tidaknya suatu kuesioner. Adapun hasil uji validitas dalam penelitian ini dapat dilihat pada Tabel 1, sebagai berikut:

Tabel 1

Hasil Uji Validitas

\begin{tabular}{ccccc}
\hline Variabel & Indikator & $r_{\text {hitung }}$ & $r_{\text {tabel }}$ & Keterangan \\
\hline & $X_{1.1}$ & 0,795 & 0,172 & Valid \\
Quality of Work Life & $X_{1.2}$ & 0,692 & 0,172 & Valid \\
$\left(X_{1}\right)$ & $X_{1.3}$ & 0,800 & 0,172 & Valid \\
& $X_{1.4}$ & 0,465 & 0,172 & Valid \\
& $X_{1.5}$ & 0,720 & 0,172 & Valid \\
& $X_{1.6}$ & 0,781 & 0,172 & Valid \\
& $X_{1.7}$ & 0,659 & 0,172 & Valid \\
& $X_{2.1}$ & 0,783 & 0,172 & Valid \\
Lamalid Kerja & $X_{2.2}$ & 0,716 & 0,172 & Valid \\
$\left(X_{2}\right)$ & $X_{2.3}$ & 0,458 & 0,172 & Valid \\
& $X_{2.4}$ & 0,653 & 0,172 & Valid \\
& $X_{2.5}$ & 0,679 & 0,172 & Valid \\
& $X_{2.6}$ & 0,653 & 0,172 & Valid \\
Kinerja & $X_{2.7}$ & 0,734 & 0,172 & Valid \\
Karyawan & $Y_{1}$ & 0,638 & 0,172 & Valid \\
$(Y)$ & $Y_{2}$ & 0,595 & 0,172 & Valid \\
& $Y_{3}$ & 0,666 & 0,172 & Valid \\
& $Y_{4}$ & 0,660 & 0,172 & Valid \\
\hline
\end{tabular}

Seperti pada Tabel 1, diketahui bahwa seluruh item dalam penelitian ini dikatakan valid untuk digunakan sebagai instrumen dalam penelitian, semua item pernyataan dalam variabel memiliki $r_{\text {hitung }}>r_{\text {tabel }} 0,172$ dengan tingkat signifikansi $5 \%$.

\section{Uji Reliabilitas}

Uji reliabilitas digunakan untuk mengetahui apakah instrumen yang digunakan dapat dipercaya atau handal sebagai alat ukur variabel. Berikut adalah penyajian Tabel 2.

Tabel 2

Hasil Uji Reliabilitas

\begin{tabular}{cccc}
\hline Variabel & Cronbach's Alpha & Standar Reliabilitas & Keterangan \\
\hline Quality of Work Life & 0,826 & 0,60 & Reliabel \\
Kinerja Karyawan & 0,770 & 0,60 & Reliabel \\
Lama Kerja & 0,779 & 0,60 & Reliabel \\
\hline
\end{tabular}

Pada Tabel 2 dapat dilihat hasil uji reliabilitas menunjukkan bahwa Cronbach's Alpha seluruh variabel lebih besar dari 0,60. Hal ini dapat dikatakan seluruh pernyataan yang digunakan dalam penelitian dinyatakan reliabel (dapat dihandalkan) sehingga selanjutnya item masing masing variabel layak digunakan untuk alat ukur variabel.

\section{Uji Normalitas}

Uji normalitas bertujuan untuk mengetahui apakah data penelitian berdistribusi normal atau tidak. Hasil uji normalitas dapat dilihat di Tabel 3. 
Tabel 3

Hasil Kolmogorov-Smirnov

\begin{tabular}{llr}
\hline \multicolumn{2}{c}{ One-Sample Kolmogorov-Smirnov Test } \\
$N$ & & Unstandardized Residual \\
Normal Parameters ${ }^{a, b}$ & Mean & 130 \\
& Std. Deviation & 0,0000000 \\
Most Extreme & Absolute & 0,15778689 \\
Differences & Positive & 0,070 \\
& Negative & 0,070 \\
Test Statistic & & $-0,053$ \\
Asymp. Sig. (2-tailed) & 0,070 \\
\hline T. Test distribution is Normal. & $0,199^{c}$ \\
\hline
\end{tabular}

a. Test distribution is Normal.

b. Calculated from data.

Seperti pada Tabel 3, dapat dilihat bahwa nilai signifikansi Asymp. Sig sebesar 0,199 > 0,05, maka disimpulkan bahwa data berdistribusi normal.

\section{Uji Multikolinearitas}

Uji ini bertujuan untuk menguji apakah dalam model regresi sederhana ditemukan adanya korelasi antara variabel bebas. Hasil uji multikolinearitas dapat dilihat pada Tabel 4.

Tabel 4

Hasi Uji Multikolinearitas

\begin{tabular}{llcc}
\hline \multicolumn{3}{c}{ Coefficients $^{a}$} \\
\cline { 3 - 4 } Model & \multicolumn{2}{c}{ Collinearity Statistics $^{\text {Tolerance }}$} \\
\hline 1 & (Constant) & & \\
& QWL & 0,031 & 32,754 \\
& Lama Kerja & 0,044 & 22,547 \\
& QWL.LamaKerja & 0,011 & 89,708 \\
\hline
\end{tabular}

a. Dependent Variable: Kinerja Karyawan

Seperti pada Tabel 4, terlihat bahwa hasil uji multikolinearitas menunjukkan nilai tolerance semua variabel bebas kurang dari 0,10 dan nilai VIF semua variabel lebih besar dari 10. Hal ini berarti terjadi Multikolinearitas. Penulis melakukan transformasi data dengan logaritma natural (LN). Kemudian, data diuji ulang setelah berikut ini hasil pengujian multikolinieritas:

\section{Tabel 5}

Hasi Uji Multikolinearitas Setelah Data Ditransformasi

\begin{tabular}{lllc}
\hline \multicolumn{3}{c}{ Coefficients $^{a}$} \\
\cline { 3 - 4 } \multicolumn{2}{c}{ Model } & \multicolumn{2}{c}{ Collinearity Statistics } \\
\hline \multirow{2}{*}{1} & (Constant) & & Tolerance \\
& LN_LamaKerja & 0,155 & 8,716 \\
& LN_QWL.LamaKerja & 0,155 & 8,716 \\
\hline
\end{tabular}

a. Dependent Variable: LN_Kinerja Karyawan

Seperti pada Tabel 5 terlihat bahwa setelah transformasi data menunjukkan nilai tolerance semua variabel bebas lebih dari 0,10 dan nilai VIF semua variabel lebih kecil dari 10. Hal ini berarti sudah tidak terjadi Multikolinearitas.

\section{Uji Heteroskedastisitas}

Model regresi yang baik yaitu terjadi homoskedastisitas dan tidak terdapat heterokedastisitas. Salah satu cara untuk melihat adanya masalah heteroskedastisitas adalah dengan Uji Glejser. Hasil uji glejser dapat dilihat di Tabel 6. 
Tabel 6

Hasi Uji Heteroskedastisitas

\begin{tabular}{|c|c|c|c|c|c|c|}
\hline \multicolumn{7}{|c|}{ Coefficients ${ }^{a}$} \\
\hline & \multirow{2}{*}{ Model } & \multicolumn{2}{|c|}{ Unstandardized Coefficients } & \multirow{2}{*}{$\frac{\text { Standardized Coefficients }}{\text { Beta }}$} & \multirow{2}{*}{$t$} & \multirow{2}{*}{ Sig. } \\
\hline & & $B$ & Std. Error & & & \\
\hline \multirow[t]{3}{*}{1} & (Constant) & 2,826 & 0,725 & & 3,896 & 0,000 \\
\hline & QWL & 0,003 & 0,038 & 0,011 & 0,074 & 0,941 \\
\hline & LamaKerja & 0,058 & 0,043 & 0,198 & 1,343 & 0,182 \\
\hline
\end{tabular}

a. Dependent Variable: RES_2

Seperti pada Tabel 6, menunjukkan bahwa seluruh nilai signifikansi variabel lebih besar dari 0,05, Jadi disimpulkan bahwa tidak terjadi heteroskedastisitas pada model regresi.

\section{Uji Koefisien Determinasi $\left(R^{2}\right)$}

Koefisien determinasi $\left(R^{2}\right)$ pada intinya mengukur seberapa jauh kemampuan model dalam menerangkan variasi variabel dependen. Hasil koefesien determinasi antara variabel dapat dilihat pada Tabel 7.

Seperti pada Tabel 7, koefisien determinasi meningkat menjadi 0,739 atau 73,9\%. Dari hasil tersebut dapat dijelaskan bahwa 73,9\% Kinerja Karyawan dapat dijelaskan Quality of Work Life dan Lama Kerja sebagai variabel moderating. Lama Kerja sebagai variabel moderating memperkuat dalam memoderasi Quality of Work Life terhadap Kinerja Karyawan, sedangkan sisanya, yaitu 26,1\% Kinerja Karyawan dijelaskan oleh variabelvariabel lainnya yang tidak diteliti dalam penelitian ini, seperti variabel kepuasan kerja, motivasi, dan kompensasi.

\section{Tabel 7}

\section{Hasil Uji $\boldsymbol{R}^{2}$}

\begin{tabular}{ccccc}
\hline \multicolumn{4}{c}{ Model Summary $^{b}$} \\
\hline Model & $R$ & $R$ Square & Adjusted $R$ Square & Std. Error of the Estimate \\
\hline 1 & $0,863^{\text {a }}$ & 0,745 & 0,739 & 1,402 \\
\hline
\end{tabular}

a. Predictors: (Constant), QWL.Lama Kerja, Lama Kerja, QWL

b. Dependent Variable: Kinerja Karyawan

\section{Uji Signifikansi (Uji F)}

Uji $F$ ini dilakukan untuk menguji apakah model yang digunakan dalam penelitian ini adalah model yang layak (fit) atau tidak. Adapun hasil analisis yang diperoleh pada Tabel 8.

\section{Tabel 8}

\section{Hasil Uji F}

\begin{tabular}{|c|c|c|c|c|c|c|}
\hline \multicolumn{7}{|c|}{$A N O V A^{a}$} \\
\hline & & Sum of Squares & $d f$ & Mean Square & $F$ & Sig. \\
\hline \multirow[t]{3}{*}{1} & Regression & 723,856 & 3 & 241,285 & 122,727 & $0,000^{\mathrm{b}}$ \\
\hline & Residual & 247,721 & 126 & 1,966 & & \\
\hline & Total & 971,577 & 129 & & & \\
\hline
\end{tabular}

a. Dependent Variable: Kinerja Karyawan

b. Predictors: (Constant), QWL.Lama Kerja, Lama Kerja, QWL

Seperti pada Tabel 8, diperoleh nilai $F_{\text {hitung }}$ sebesar 122,727 dengan probabilitas sebesar $0,00, F_{\text {hitung }}>F t_{\text {abel }}$ dan angka tersebut lebih kecil dari nilai 0,05 (5\%). Dengan demikian dapat disimpulkan bahwa model yang digunakan untuk menguji Quality of Work Life adalah model yang fit. Persamaan regresi dapat dinyatakan signifikan yang berarti bahwa Quality of Work Life dan Lama Kerja berpengaruh signifikan terhadap Kinerja Karyawan.

\section{Uji Signifikansi Parsial (Ujit)}

Pengujian hipotesis dilakukan untuk mengetahui pengaruh seluruh variabel independen terhadap variabel dependen untuk melihat kebermaknaan masing-masing variabel independen dalam model regresi yang diperoleh. Apabila nilai $t_{\text {hitung }}$ lebih besar dari $t_{\text {tabel }}$ menunjukkan diterimanya hipotesis yang diajukan. Hasil uji $t$ dapat dilihat pada Tabel 9. 
Tabel 9

Hasil Uji $t$

\begin{tabular}{|c|c|c|c|c|c|}
\hline \multicolumn{6}{|c|}{ Coefficients $^{a}$} \\
\hline \multirow{2}{*}{ Model } & \multicolumn{2}{|c|}{ Unstandardized Coefficients } & \multirow{2}{*}{$\frac{\text { Standardized Coefficients }}{\text { Beta }}$} & \multirow{2}{*}{$t$} & \multirow{2}{*}{ Sig. } \\
\hline & $B$ & Std. Error & & & \\
\hline (Constant) & 42,384 & 4,598 & & 9,218 & 0,000 \\
\hline QWL & 0,902 & 0,178 & 1,305 & 5,069 & 0,000 \\
\hline Lama Kerja & 0,749 & 0,169 & 0,948 & 4,439 & 0,000 \\
\hline QWL*Lama Kerja & 0,041 & 0,006 & 2,964 & 6,958 & 0,000 \\
\hline
\end{tabular}

a. Dependent Variable: KinerjaKaryawan

Perhitungannya sebagai berikut $d f=130-3=127$ dengan taraf signifikansi $0,05 \%$ sehingga $t_{\text {tabel }}$ yang diperoleh sebesar 1,657. Berdasarkan hasil analisis regresi untuk Quality of Work Life, Lama Kerja dan Quality of Work Life *Lama Kerja diperoleh nilai $t_{\text {hitung }}>t_{\text {tabel }}$ yaitu 5,069, 4,439 dan 6,958 > 1,657. Nilai signifikansi (sig.) masing-masing sebesar $0,000<0,05$, maka dapat disimpulkan bahwa $H_{l}$ diterima yang artinya Quality of Work Life memiliki pengaruh signifikan terhadap Kinerja Karyawan. Lama Kerja sebagai variabel moderating dapat disimpulkan bahwa dapat memperkuat dalam memoderasi Quality of Work Life terhadap kinerja karyawan.

\section{Quality of Work Life terhadap Kinerja Karyawan}

Berdasarkan hasil pengujian tersebut diketahui bahwa Quality of Work Life berpengaruh positif signifikan terhadap kinerja karyawan. Nilai koefisien regresi sebesar 0,526 yang memiliki arah positif mengindikasikan bahwa semakin baik Quality of Work Life, maka akan semakin meningkatkan Kinerja Karyawan. Hasil ini konsisten dengan penelitian Astuti (2017) yang menyatakan bahwa Quality of Work Life berpengaruh signifikan terhadap kinerja karyawan dan menyatakan semakin baik Quality of Work Life akan semakin meningkatkan kinerja karyawan, sehingga hipotesis satu $\left(H_{l}\right)$ yang menyatakan Quality of Work Life berpengaruh positif dan signifikan terhadap kinerja karyawan pada PT. PLN (Persero) UIP3BS UPT Medan diterima.

\section{Pengaruh Quality of Work Life terhadap Kinerja Karyawan Dimoderasi oleh Lama Kerja}

Berdasarkan hasil pengujian tersebut diketahui bahwa Lama Kerja sebagai variabel moderasi dapat disimpulkan memperkuat dalam memoderasi Quality of Work Life terhadap Kinerja Karyawan. Pengaruh positif antara Quality of Work Life terhadap kinerja karyawan akan menjadi lebih kuat untuk karyawan yang sudah lama bekerja. Nilai koefisien regresi sebesar 0,041 yang memiliki arah positif mengindikasikan bahwa semakin lama karyawan bekerja semakin tinggi pula Quality of Work Life yang dirasakan selama bekerja, semakin baik kualitas kehidupan kerja yang dilakukan perusahaan maka semakin meningkat pula Kinerja Karyawan. Hasil ini konsisten dengan penelitian Rahmadani (2017) yang menyatakan bahwa lama bekerja berhasil memoderasi antara kepuasan kerja dengan kinerja. Kepuasan kerja merupakan salah satu yang berkenaan dengan Quality of Work Life, maka karyawan yang mempunyai masa kerja yang lama merasa puas dalam bekerja, begitu pula sebaliknya, karyawan yang masih baru akan menyesuaikan diri dengan lingkungan kerja, sehingga kepuasan karyawan terhadap pekerjaan belum tinggi, dan kinerja yang dihasilkan belum sesuai dengan yang diharapkan oleh perusahaan, sehingga hipotesis satu $\left(\mathrm{H}_{2}\right)$ yang menyatakan Lama kerja dapat memoderasi pengaruh Quality of Work Life terhadap kinerja karyawan pada PT. PLN (Persero) UIP3BS UPT Medan diterima.

\section{Simpulan, Keterbatasan, dan Saran}

Berdasarkan tanggapan responden kualitas kehidupan kerja sudah diterapkan dengan baik atau termasuk ke dalam kriteria sangat baik. Kinerja karyawan PT. PLN (Persero) UIP3BS UPT Medan sangat memuaskan, jadi untuk pencapaian kinerja karyawan sudah diterapkan dengan baik atau termasuk ke dalam kategori sangat baik. Hasil penelitian ini mendukung hipotesis $\left(H_{l}\right)$ yang diajukan, hal ini berarti Quality of Work Life memiliki pengaruh yang positif dan signifikan terhadap Kinerja Karyawan. Hasil penelitian ini mendukung hipotesis $\left(H_{2}\right)$ yang diajukan, hal ini berarti Lama Kerja merupakan variabel moderating yang memperkuat terhadap hubungan antara Quality of Work Life dengan Kinerja Karyawan. 
Keterbatasan dari penelitian ini adalah wilayah populasi yang terlalu sempit, untuk itu disarankan kepada peneliti selanjutnya agar memperluas wilayah populasi yang diteliti, sehingga hasil penelitian dapat digeneralisasikan, tidak hanya terbatas pada karyawan PT. PLN (Persero) UIP3BS UPT Medan saja.

Saran yang dapat diberikan kepada perusahaan yaitu diharapkan untuk perusahaan baik yang menjadi subjek penelitian ini ataupun di luar penelitian ini, untuk memperhatikan beberapa faktor tersebut untuk mengoptimalkan kinerja karyawan. Dari segi kualitas kehidupan kerja yang dilakukan oleh perusahaan sudah baik dan untuk kedepannya lebih ditingkatkan lagi kulaitas kehidupan kerja untuk karyawan PT. PLN (Persero) UIP3BS UPT Medan, sehingga keamanan dan kenyamanan dalam bekerja dapat dirasakan karyawan, seperti memperhatikan indikator kualitas kehidupan kerja berupa lingkungan kerja yang baik dan nyaman. Di samping itu, ditingkatkan lagi pada beberapa indikator lainnya seperti partisipasi dalam pekerjaan untuk menjalin hubungan lebih dekat dengan rekan kerja maupun atasan dan guna menciptakan suasana kekeluargaan bagi karyawan.

\section{Referensi}

Mangkunegara, A. A. A. P. (2009). Manajemen sumber daya manusia. Bandung: Remaja Rosdakarya.

Aprilyanti, S. (2017). Pengaruh usia dan masa kerja terhadap produktivitas kerja (Studi kasus: PT. Oasis Water International Cabang Palembang). Jurnal Sistem dan Manajemen Industri, 1(2), 68-72.

Astuti, W. (2017). Pengaruh quality of work life terhadap kinerja karyawan PT. BNI Syariah Palembang. Doctoral Dissertation. UIN Raden Fatah.

Cascio, W. F. (2006). Managing human resources - Productivity, quality of work life, profits. Edisi Ke-5. United States: Mcgraw-Hill.

Hadi, A. (2008). Pengaruh kualitas kehidupan kerja dan komitmen organisasional terhadap kinerja pegawai di PT. Bank Jabar Banten. Tesis tidak diterbitkan, Program Magister Manajemen Pasca Sarjana UNPAD.

Handoko, T. H. (2001). Manajemen personalia dan sumberdaya manusia. Edisi Kedua. Yogyakarta: BPFE. Ivancevich, J. M. (2007). Perilaku \& manajemen organisasi. Jakarta: Erlangga.

Moeheriono. (2009). Pengukuran kinerja berbasis kompetensi. Bogor: Ghalia.

Pruijt, H. (2003). Performance and quality of work life. Journal of Organizational Change Management, 13, 389-400.

Rahmadani, F. (2017). Analisis pengaruh kompensasi, motivasi kerja dan kepuasan kerja terhadap kinerja karyawan pada CV. Fawas Jaya Medan dengan lama kerja sebagai variabel moderating. Skripsi, Universitas Islam Negeri Sumatera Utara.

Robbins, S. P. (2006). Perilaku organisasi. Edisi Kesepuluh. Jakarta: Prenhallindo.

Setiyadi, Y. W., Wartini, S., \& Wijayanto, A. (2016). Pengaruh kualitas kehidupan kerja terhadap kinerja karyawan dengan kepuasan kerja sebagai variabel intervening. Management Analysis Journal, 5(4), 315-324.

Sugiyono. (2016). Metode penelitian kuantitatif, kualitatif dan R\&D. Bandung: PT Alfabet.

Zin, R. M. (2004). perception of professional engineers toward quality of work life and organizational commitment a case study. Gadjah Mada International Journal of Business, 6(3), 323-334. 